\title{
Identification and Inheritance of Delayed First Pustule Appearance to Common leaf Rust in Sweet Corn
}

\author{
G.R. Gingera ${ }^{1}$ and D.W. Davis ${ }^{2}$ \\ Department of Horticultural Science, University of Minnesota, St. Paul \\ J.V. Groth ${ }^{2}$ \\ Department of Plant Pathology, University of Minnesota, St. Paul, MN 55108
}

Additional index words. Zea mays, Puccinia sorghi, partial resistance, rate-limiting resistance, latent period, first pustule appearance, vegetable breeding, components of resistance, biocontrol, sustainable agriculture

\begin{abstract}
Partial resistance effectively reduces common leafrust (Puccinia sorghi Schw.) epidemics in sweet corn (Zea mays L.). One measurable field component of partial resistance is delayed first pustule appearance (FPA), influenced by latent period and infection efficiency. This is the first report of delayed FPA against common rust in sweet corn. Our objectives were to determine 1) if differences in delayed FPA could be assessed in a field environment, 2) the relationship between delayed FPA and disease severity, and 3) the inheritance of delayed FPA. FPA was screened in a field environment during 1992 and 1993 using two susceptible U.S. station inbreds and 32 breeding lines selected for partial resistance to common rust. The range in mean delay in FPA on a genotype basis was 2.4 to 5.0 days in 1992 and 1.5 to 7.4 days in 1993. Although the rank correlation of genotypes between years was small $(r=0.27)$, several breeding lines had longer delayed FPA in both years while others produced shorter FPA delay in both years. Seven commercial sweet corn hybrids with a wide range of partial resistance did not differ $(P \leq \mathbf{0 . 0 5})$ for delayed FPA. There was no correlation between disease severity and delayed FPA $\left(r^{2}=0.00\right.$ to 0.21$)$ for breeding lines or commercial hybrids, indicating that selection for delayed FPA may be conducted independently of disease severity. In a generation mean analysis conducted in 1993 and 1994 for three high $x$ low delayed FPA crosses, the genetic control of delayed FPA was primarily additive. Dominant genetic effects were found in two crosses and epistasis was not significant in any cross.
\end{abstract}

Common rust of maize maybe controlled by partial or hypersensitive resistance. More than 20 hypersensitive resistance $(R p)$ genes have been identified against common rust in corn germplasm (Hooker, 1969). Most of these genes are dominant, and virulence against many of these genesis found in field populations of common rust in the continental United States (Groth et al., 1992). Several $R p$ genes that provide effective protection in the midwest are $R p_{1}{ }_{1}, R p_{3}{ }^{C}, R p_{1}{ }^{l}, R p_{1}{ }^{k}, R p_{1}{ }^{e}$, and $R p_{1}{ }^{g}$. The potential for virulence to develop against effective $R p$ genes in the midwest may limit the long-term usefulness of $R p$ resistance. In Hawaii, where the host and pathogen interact throughout the season, no single $R p$ has remained effective (Brewbaker, 1983). As there is no evidence for race-specific interactions for partial resistance, this approach may provide greater long-term protection than hypersensitive resistance.

Partial resistance is composed of individual components that reduce the rate of disease buildup. These components involve spore production and viability, such as spores per uredinia, spores per lesion, or sporulation duration (Parlevliet, 1993). Time-based components such as latent period (LP) also reduce epidemic development by increasing the time necessary to complete a disease cycle. Alternatively, a lower infection efficiency slows the progress of epidemics by reducing the proportion of spores that infect potential host plants (Parlevliet, 1993).

Partial resistance against common rust has been identified in

Received for publication 11 Mar. 1994. Accepted for publication 27 Oct. 1994 Univ. of Minnesota Agricultural Experiment Station Scientific Publication Series paper no. 21060. Support for this research was provided by a grant from the Midwest Food Processors Association. The cost of publishing this paper was defrayed in part by the payment of page charges. Under postal regulations, this paper therefore must be hereby marked advertisement solely to indicate this fact. 'Graduate research assistant.

${ }^{2}$ Professor. field corn (Hooker, 1969; Kim and Brewbaker, 1977) and sweet corn (Groth et al., 1983; Pataky, 1986; Gingera et al., 1994). Pataky (1986) identified differences-among sweet corn commercial hybrids for individual components such as uredinial number, spores per uredinium, uredinial size, and spore production. There have been no published reports of maize germplasm tested for potential components of partial resistance to common rust.

Most selection for partial resistance to plant diseases is based on assessments of disease severity. An effective strategy for increasing partial resistance is to combine genotypes having different components that are inherited independently and which are additive in their effect. Combining specific components may prove to be difficult; in bean rust, uredinial size and infection efficiency have been shown to be highly influenced by pustule and host tissue age (Groth and Urs, 1982). Estimates of infection efficiency require standardized inoculum densities and control of tissue age, neither of which is possible during the course of field epidemics. One potential component of resistance is the appearance of the first uredinia on young, previously uninfected leaves. Delayed first pustule appearance (FPA) reflects differences in LP, possibly combined with differences in infection efficiency since only the first successful infections and pustules are recorded.

Differences in LP have been documented in various hostpathogen systems, and Leonard and Mundt (1983) theorized that lengthened LP could effectively reduce population growth for polycyclic pathogens such as the cereal rusts. Parlevliet (1975) reported differences among barley cultivars for LP against $P$. hordei. The LP of susceptible and resistant wheat lines ranged from 8.3 to 13.9 days against Septoria nodorum (Wilkinson et al., 1990). Rashid (1991) found a range of LP from 7.0 to 9.0 days among eleven flax cultivars against three races of Melampsora lini. LP ranged from 11.6 to 18.5 days for blue mold (Peronospora tabacina) resistance in tobacco with an LSD of 1.0 day (Rufty and 
Main, 1989). Zummo (1988) reported variation for pustule incidence against southern corn rust (Puccinia polysora) between field and controlled environment tests. Both tests differentiated susceptible and resistant hybrids.

Patty (1986) determined that there were no differences in LP among commercial sweet corn hybrids with a wide range of partial resistance. We are not aware of any published reports of LP or delayed FPA against common rust using breeding lines or noncommercial germplasm. Our objectives were to determine 1) whether differences in FPA could be assessed in a field environment, 2) the relationship between mean FPA and disease severity, and 3) the inheritance of delayed FPA.

\section{Materials and Methods}

Two experiments were conducted to identify delayed FPA in breeding lines and commercial hybrids. A third experiment was designed to investigate the inheritance of delayed FPA.

FPA assessments were made in 1992, 1993, and 1994 at St. Paul, Minn. A disease spreader comprised of a mechanical mixture of several rust susceptible commercial sweet corn hybrids was planted on 15 May 1992, 14 May 1993, and 20 May 1994, along field margins and at the head and foot of each $3.3-\mathrm{m}$, single-row experimental plot. The spreader was inoculated on 7 June 1992, 8 June 1993, and 5 June 1994. A mini-ulva was used to atomize 0.25 $\mathrm{g}$ frozen urediniospores suspended in 1 liter of soltrol (Phillips, Bartlesville, Okla.) above the spreader canopy. Urediniospores produced on spreader leaves were windborne onto leaves of the test plants, simulating natural dispersal.

Delayed FPA among breeding lines. Delayed FPA was examined in $32 \mathrm{~F}_{4}$ or $\mathrm{F}_{5}$ sugary sweet corn breeding lines based on their ability to delay the onset of rust in inoculated trials. The lines were chosen from 10 parentages in a pedigree selection program (Gingera et al., 1994), none of which was known to possess partially effective $R p$ resistance genes in its pedigree. Partially effective $R p$ resistance would artificially inflate delayed FPA estimates by reducing the infection efficiency or proportion of spores that could infect plants.

The 32 breeding lines and 2 rust-susceptible U.S. station inbred lines, C 13 and Ia453, were randomized in a completely randomized design. Due to the large number of lines used and the high labor requirement in assessing FPA, a single replicate of each entry was evaluated each year. About 25 kernels of each line were handplanted on 5 and 10 June 1992 and 1993, respectively. Weak or offtype plants were culled 1 week after emergence and stand was recorded.

The effect of distance to the spreader was assessed to determine whether interplot interference affected date of FPA. Each plot was divided into two sections (i.e., head and foot) and the two plants closest to the spreader (at opposite ends of each plot) were paired as Position 1. Position 2 was defined by the next two plants adjacent to Position 1; this procedure was continued until all plants in each plot had been defined.

Each year, about 10 days after spreader inoculation, the date of FPA was determined by examining each plant for erupted pustules on abaxial and adaxial leaf surfaces. Data were collected only on true leaves as pustules on coleoptiles were ignored to minimize differences in coleoptile sizes among lines. Day 1 was designated as the day when the first experimental plant produced at least one fully erupted pustule. Each day following Day 1, plants not previously having rust pustules were examined. The exact FPA date for each plant was recorded. Data were collected over a total of 7 and 11 days in 1992 and 1993, the range of FPA in each year.
Four disease-severity assessments were conducted on each plant by using a 0-9 rating scale (Davis et al., 1988) at maize vegetative (V) growth stages V5 and V8 and reproductive (R) stages R1 and R3 (Ritchie and Hanway, 1982). Two sets of disease assessments were collected for each plant at each growth stage: 1) mean disease severity of the upper six leaves and 2) the severity of the most diseased leaf of the upper six leaves.

All data analyses were conducted using SAS (SAS Institute, Cary, N.C.). Analysis of variance (ANOVA) was used to partition effects due to genotype, year, and position. A separate analysis for each year was conducted as there was a significant genotype $\mathrm{x}$ year interaction for the combined analysis. The stability of delayed FPA on a genotype mean basis was determined by performing a rank correlation between the 2 years.

Variation among commercial hybrids for delayed FPA. Seven commercial hybrids, representing a wide range of partial resistance, were included in a two-replicate factorial experiment in 1993. The resistant hybrids used were 'Sweetie 82', 'Rely', and 'Miracle' and the susceptible hybrids were 'Pegasus', 'Florida Staysweet (FSS)', and 'Sterling'. 'Jubilee' was included as it is moderately susceptible to common rust (Pataky, 1992). Plots were planted on 3 June 1993. Cultural practices, epidemic development and data collection were the same as above. A factorial ANOVA was used to partition replicate, genotypic, and plant position effects for FPA and disease severity.

Inheritance of delayed FPA. Based on significant differences among lines for date of FPA in 1992, an inheritance study was conducted in 1993 and 1994 to assess the genetic control of delayed FPA. Three Minnesota lines with the longest delayed FPA $\left(1267,1278\right.$, and 1291) $\left(\mathrm{P}_{1}\right)$ were crossed to $\mathrm{C} 13\left(\mathrm{P}_{2}\right)$, the line with the earliest FPA. Each $\mathrm{F}_{1}$ was advanced to the $\mathrm{F}_{2}$ and backcrossed to develop $\mathrm{BC}_{1} \mathrm{P}_{1}$ and $\mathrm{BC}_{1} \mathrm{P}_{2}$. Two additional crosses ( $1291 \mathrm{x}$ Ia453 and $1269 \times \mathrm{C} 13$ ) were advanced to the $\mathrm{F}_{2}$ to obtain additional data on FPA inheritance. All generations from each cross were grown in a field rust nursery using a randomized complete block with two replicates per generation. Each $\mathrm{F}_{2}$ was planted in six plots and all other generations were planted in two plots each. In 1993, all five crosses were evaluated but in 1994, only the three crosses with backcross generations were tested. Field protocols were as above, except that in 1994 the entries were planted on 10 June. Disease severity was assessed at growth stages V8 and R3 (Ritchie and Hanway, 1982) in both years.

A generation mean analysis (Gamble, 1962) was conducted to assess the genetic basis for delayed FPA. Following an ANOVA for both FPA and disease severity, a separation of genetic effects was conducted by using linear regression (Hayman, 1958). Partitioning of genetic effects was conducted by using additive, dominant, and epistatic components. Separation of individual genetic effects was completed when no significant variation remained in the original sums of squares.

\section{Results}

Delayed FPA among breeding lines. There were differences $(P$ $\leq 0.05)$ for delayed FPA among the 34 Minnesota breeding lines and susceptible inbred lines (Table 1). C 13 developed the shortest FPA in both years (2.4 and 1.5 days). Line 1278 had the longest FPA in 1992 (5.0 days), and in 1993, line 1291 had the longest FPA (7.4 days). Date of FPA across genotypes differed by 2.6 and 5.9 days in 1992 and 1993, respectively, and tended to be earlier for most entries in 1992 than in 1993. Genotype performance between the 2 years was variable as the rank correlation between years was moderately low $(r=0.27)$. Lines with the shortest FPA delay were 
responsible for the greatest proportion of genotype $\mathrm{x}$ year interaction (data not shown). Lines with the longest delay in FPA had the least genotype $\mathrm{x}$ year interaction and produced longer delayed FPA in both years. Several lines changed rank greatly between 1992 and 1993 (Table 1). There was no relationship between FPA and mean or worst leaf disease severity $\left(r^{2} \leq 0.08\right)$ for any of the four disease assessment dates. There was no effect of plant position within rows for either FPA or disease severity $(P \geq 0.05)$.

Variation among commercial hybrids for delayed FPA. The commercial hybrids did not differ $(P \geq 0.05)$ for FPA (due to a nonsignificant ANOVA model), despite a large difference in partial resistance at all growth stages (Table 2). There was no relationship between date of FPA and disease severity $\left(r^{2} \leq 0.22\right)$ for any growth stage. Plant position did not affect FPA or disease severity (data not presented) $(P \geq 0.05)$.

Inheritance of delayed FPA. There were differences for delayed FPA among generations in 1993 and 1994 (Tables 3 and 4). The resistant parents $\left(\mathrm{P}_{1}\right)$ had a greater delayed FPA than the susceptible parents $\left(\mathrm{P}_{2}\right)$ for all crosses. The $\mathrm{F}_{1}$ was equal to or had an earlier FPA compared to $\mathrm{P}_{1}$, depending on the cross. There was no evidence of high parent heterosis as the $F_{1}$ did not exceed $(P \geq 0.05)$ $\mathrm{P}_{1}$. Transgressive segregation was not evident, as individual $\mathrm{F}_{2}$ plants did not exceed the FPA of either parent.

In 1993, there were no significant differences between PI,
$\mathrm{BC}_{1} \mathrm{P}_{1}, \mathrm{~F}_{1}$ and $\mathrm{BC}_{1} \mathrm{P}_{2}$ for the $1267 \times \mathrm{C} 13$ and $1278 \times \mathrm{C} 13$ crosses, but the $\mathrm{F}_{2}$ and $\mathrm{P}_{2}$ had less delay of FPA (Table 3). In 1994, all generations except $\mathrm{P}_{2}$ for the $1278 \times \mathrm{C} 13$ cross produced similar date of FPA (Table 4). $\mathrm{BC}_{1} \mathrm{P}_{1}$, and $\mathrm{BC}_{1} \mathrm{P}_{2}$ demonstrated similar FPA for the 1267 x C13 cross. For the 1291 x C13 cross in 1993, $\mathrm{P}_{1}$ had a longer FPA than all other generations; there were no differences among the $\mathrm{BC}_{1} \mathrm{P}_{2}, \mathrm{~F}_{1}, \mathrm{BC}_{1} \mathrm{P}_{2}$, and $\mathrm{F}_{2}$. In 1994 the $\mathrm{F}_{1}$, $\mathrm{BC}_{1} \mathrm{P}_{1}$, and $\mathrm{F}_{2}$ developed similar FPA, however, the $\mathrm{BC}_{1} \mathrm{P}_{2}$ developed a shorter FPA than other generations.

Genetic control of FPA varied among the three crosses that included backcross generations (Table 5). A large proportion of the genetic variation was explained by additive effects. Significant dominant effects were detected in the $1267 \times \mathrm{C} 13$ and $1278 \times \mathrm{C} 13$ crosses in 1993 and 1994. The 1291 x C 13 cross did not exhibit dominant effects in either year. Epistatic effects were not significant in any cross.

Differences for mean and worst leaf disease severity among generations were similar to differences in delayed FPA (Tables 6 and 7). $P_{1}$ was more resistant than $P_{2}$ at all growth stages. The $F_{1}$ was intermediate in disease severity compared to the parents, and the $\mathrm{BC}_{1} \mathrm{P}_{1}$ often developed less rust $(P \leq 0.05)$ than the $\mathrm{BC}_{1} \mathrm{P}_{2}$. The $\mathrm{BC}_{1} \mathrm{P}_{1}$ and resistant parents were similar in disease severity at V5; however greater differences among the generations often were observed by R3.

Table 1. Mean delay (days) of first pustule appearance (FPA) and ranking of breeding lines and U.S. station inbreds in a field leaf rust nursery in 1992 and 1993.

\begin{tabular}{|c|c|c|c|c|c|c|c|c|c|c|c|c|c|c|}
\hline \multirow[b]{2}{*}{ Line } & \multicolumn{2}{|c|}{1992} & \multicolumn{2}{|c|}{1993} & \multirow[b]{2}{*}{ Line } & \multicolumn{2}{|c|}{1992} & \multicolumn{2}{|c|}{1993} & \multirow[b]{2}{*}{ Line } & \multicolumn{2}{|c|}{1992} & \multicolumn{2}{|c|}{1993} \\
\hline & $\mathrm{FPA}^{2}$ & $\operatorname{Rank}^{y}$ & $\overline{\text { FPA }}$ & Rank & & FPA & Rank & FPA & $\overline{\operatorname{Rank}}$ & & FPA & Rank & FPA & Rank \\
\hline$\overline{1278}$ & 5.0 & 1 & 6.7 & 5 & 1272 & 3.8 & 12 & 5.7 & 15 & $\overline{\mathrm{Ia} 453}$ & 3.4 & 25 & 4.6 & 32 \\
\hline 1291 & 4.7 & 2 & 7.4 & 1 & 1279 & 3.8 & 12 & 5.2 & 24 & 1281 & 3.4 & 25 & 5.7 & 15 \\
\hline 1267 & 4.6 & 3 & 6.1 & 10 & 1277 & 3.7 & 15 & 6.4 & 7 & 1274 & 3.3 & 27 & 6.1 & 10 \\
\hline 1273 & 4.1 & 4 & 5.5 & 21 & 1287 & 3.7 & 15 & 5.7 & 15 & 1280 & 3.2 & 28 & 6.8 & 4 \\
\hline 1268 & 4.1 & 4 & 5.7 & 15 & 1286 & 3.7 & 15 & 6.2 & 8 & 1294 & 3.2 & 28 & 5.9 & 13 \\
\hline 1315 & 4.1 & 4 & 5.4 & 22 & 1316 & 3.6 & 18 & 5.0 & 28 & 1313 & 3.2 & 28 & 5.1 & 26 \\
\hline 1269 & 4.1 & 4 & 7.0 & 2 & 1288 & 3.6 & 18 & 5.1 & 26 & 1282 & 3.1 & 31 & 6.5 & 6 \\
\hline 1271 & 4.1 & 4 & 5.6 & 20 & 1270 & 3.6 & 18 & 7.0 & 2 & 1283 & 3.0 & 32 & 5.2 & 24 \\
\hline 1293 & 3.9 & 9 & 6.2 & 8 & 1289 & 3.6 & 18 & 4.7 & 31 & 1284 & 2.6 & 33 & 5.9 & 13 \\
\hline 1314 & 3.9 & 9 & 5.0 & 28 & 1276 & 3.6 & 18 & 6.0 & 12 & C13 & 2.4 & 34 & 1.5 & 34 \\
\hline 1290 & 3.9 & 9 & 5.4 & 22 & 1295 & 3.5 & 23 & 4.3 & 33 & & & & & \\
\hline 1275 & 3.8 & 12 & 5.7 & 15 & 1296 & 3.5 & 24 & 4.9 & 30 & & & & & \\
\hline
\end{tabular}

LSD for delay of FPA 0.63 (1992); 1.61 (1993).

${ }^{y}$ Rank assigned based on sorting lines in descending order of mean delay of FPA for each year; rank correlation between years $r=0.27$.

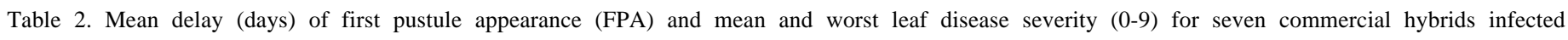
by common rust in a field nursery in 1993 .

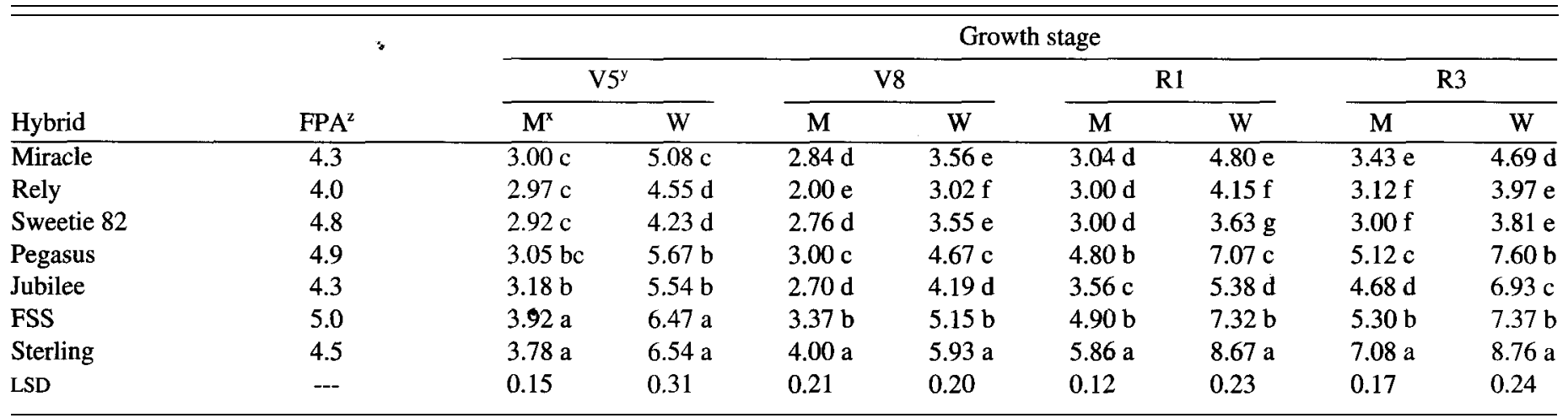

${ }^{2}$ Nonsignificant ANOVA(P $\left.\geq 0.05\right)$ for delayed FPA among commercial hybrids.

${ }^{y}$ Means with different letters within columns are significantly different $(\mathrm{P} \leq 0.05)$.

${ }^{x}$ Mean (M) and worst (W) leaf disease severity ratings for each growth stage. 
Table 3. Means and standard errors of delay (days) of first pustule appearance (FPA) against common rust for each generation of sweet corn used in a generation mean analysis in 1993 .

\begin{tabular}{|c|c|c|c|c|c|c|c|c|c|c|}
\hline \multirow[b]{3}{*}{ Generation } & \multicolumn{10}{|c|}{ Cross } \\
\hline & \multicolumn{2}{|c|}{$1267 \times \mathrm{C} 13$} & \multicolumn{2}{|c|}{$1278 \times \mathrm{C} 13$} & \multicolumn{2}{|c|}{$1291 \times \mathrm{C} 13$} & \multicolumn{2}{|c|}{$1269 \times \mathrm{C} 13$} & \multicolumn{2}{|c|}{$1291 \times \mathrm{Ia} 453$} \\
\hline & $\mathrm{FPA}^{z y}$ & SE & FPA & SE & FPA & $\mathrm{SE}$ & FPA $^{x}$ & SE & FPA $^{x}$ & SE \\
\hline$\overline{P_{1}}$ & $4.8 \mathrm{a}$ & 0.37 & $5.3 \mathrm{a}$ & 0.36 & $7.7 \mathrm{a}$ & 0.81 & $6.8 \mathrm{a}$ & 0.63 & $7.7 \mathrm{a}$ & 0.81 \\
\hline $\mathrm{BC}_{1} \mathrm{P}_{1}$ & $5.6 \mathrm{a}$ & 0.29 & $5.2 \mathrm{a}$ & 0.25 & $5.4 \mathrm{~b}$ & 0.35 & --- & --- & --- & --- \\
\hline $\mathrm{F}_{1}$ & $5.0 \mathrm{a}$ & 0.30 & $4.7 \mathrm{a}$ & 0.30 & $5.1 \mathrm{~b}$ & 0.45 & $3.6 \mathrm{~b}$ & 0.38 & $5.0 \mathrm{~b}$ & 0.48 \\
\hline $\mathrm{BC}_{1} \mathrm{P}_{2}$ & $4.8 \mathrm{a}$ & 0.34 & $5.5 \mathrm{a}$ & 0.37 & $4.8 \mathrm{~b}$ & 0.62 & -- & --- & --- & --- \\
\hline $\mathrm{P}_{2}$ & $1.8 \mathrm{c}$ & 0.21 & $1.8 \mathrm{c}$ & 0.21 & $1.8 \mathrm{c}$ & 0.35 & $1.8 \mathrm{c}$ & 0.21 & $4.2 \mathrm{~b}$ & 0.35 \\
\hline $\mathrm{F}_{2}$ & $3.9 \mathrm{~b}$ & 0.17 & $3.6 \mathrm{~b}$ & 0.18 & $4.5 \mathrm{~b}$ & 0.23 & $4.2 \mathrm{~b}$ & 0.22 & $4.4 \mathrm{~b}$ & 0.24 \\
\hline LSD & 0.8 & & 0.8 & & 1.3 & & 1.1 & & 1.2 & \\
\hline
\end{tabular}

${ }^{2}$ Mean days for delayed FPA.

'Means within each column with different letters are significantly different $(P \leq 0.05)$.

${ }^{x}$ Only four generations used in this cross.

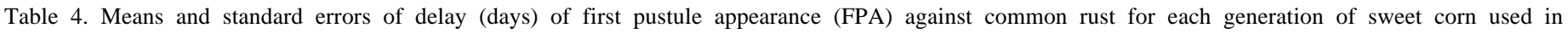
a generation mean analysis in 1994.

\begin{tabular}{|c|c|c|c|c|c|c|}
\hline \multirow[b]{3}{*}{ Generation } & \multicolumn{6}{|c|}{ Cross } \\
\hline & \multicolumn{2}{|c|}{$1267 \times \mathrm{C} 13$} & \multicolumn{2}{|c|}{$1278 \times \mathrm{C} 13$} & \multicolumn{2}{|c|}{$1291 \times \mathrm{C} 13$} \\
\hline & FPA $^{z y}$ & SE & FPA & $\mathrm{SE}$ & FPA & SE \\
\hline$\overline{\mathbf{P}_{1}}$ & $7.4 \mathrm{a}$ & 0.56 & $7.0 \mathrm{a}$ & 0.57 & $8.5 \mathrm{a}$ & 0.48 \\
\hline $\mathbf{B C}_{1} \mathbf{P}_{1}$ & $6.3 \mathrm{a}$ & 0.49 & $5.8 \mathrm{a}$ & 0.47 & $6.9 \mathrm{~b}$ & 0.38 \\
\hline$F_{1}$ & $7.1 \mathrm{ab}$ & 0.54 & $6.3 \mathrm{a}$ & 0.38 & $5.7 \mathrm{bc}$ & 0.43 \\
\hline $\mathrm{BC}_{1} \mathbf{P}_{2}$ & $6.3 a b$ & 0.75 & $6.5 \mathrm{a}$ & 0.51 & $5.5 \mathrm{c}$ & 0.54 \\
\hline $\mathrm{P}_{2}$ & $3.8 \mathrm{c}$ & 0.23 & $3.8 \mathrm{~b}$ & 0.23 & $3.8 \mathrm{~d}$ & 0.23 \\
\hline $\mathrm{F}_{2}$ & $5.8 \mathrm{~b}$ & 0.19 & $6.2 \mathrm{a}$ & 0.22 & $7.1 \mathrm{~b}$ & 0.25 \\
\hline LSD & 1.4 & & 1.5 & & 1.2 & \\
\hline
\end{tabular}

${ }^{2}$ Mean days for FPA.

${ }^{y}$ Means within each column with different letters are significantly different $(P \leq 0.05)$.

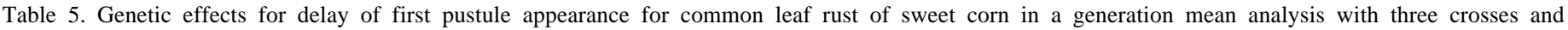
six generations.

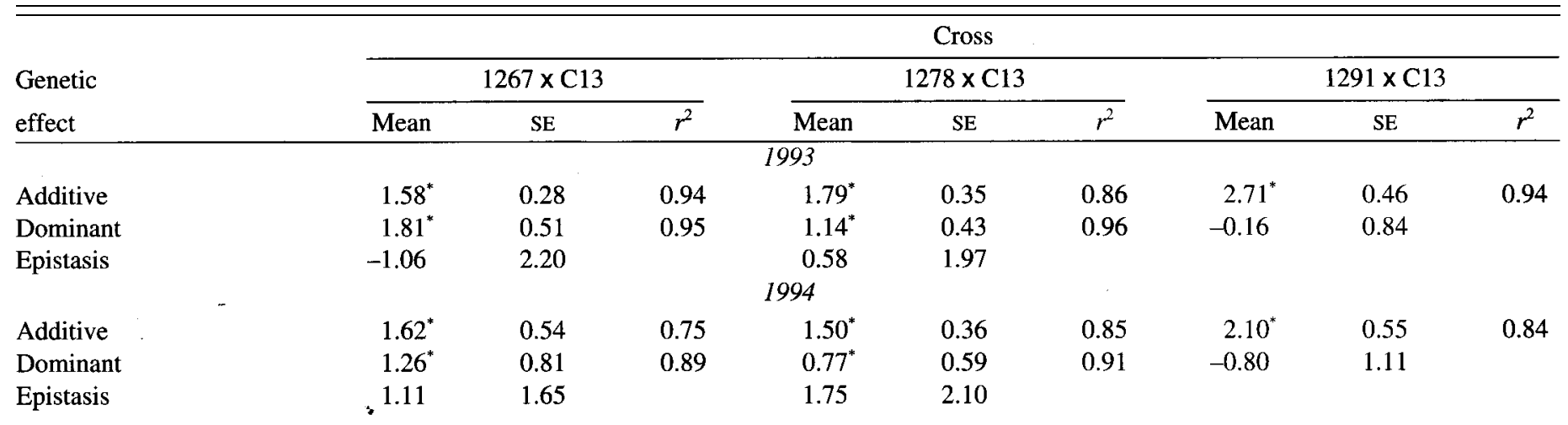

*Significant genetic effects at $P \leq 0.05$.

\section{Discussion}

This is the first report of differences among sweet corn genotypes for delayed FPA against common rust. Although differences in delayed FPA among lines could be differences in LP, the indirect inoculation of test plants confound differences of LP with infection efficiency. A direct inoculation of breeding lines could separate LP and infection efficiency effects. Differences in delayed FPA and possibly LP among breeding lines may result from the use of highly resistant exotic germplasm from tropical sources (Randle et al., 1984; Davis et al., 1990; Gingera et al., 1994).

The magnitude of differences of delay in FPA among lines was similar to those for LP assessments in other plant species (Shaner et al., 1978; Rashid, 199 1; Ruft y and Main, 1989; Parlevliet, 1975), suggesting that accurate assessments of delayed FPA may be made infield environments. Although differences among breeding lines for FPA seem fairly small (Table 1), differences such as the 2.6 and 5.9 days in 1992 and 1993 may be compounded throughout the season. Leonard and Mundt (1983) estimated that if LP could be increased from 5 to 8 days for barley rust, this increased level of resistance would correspond to a $63 \%$ reduction in sporulation or infection efficiency. Longer FPA may also function to reduce inoculum production progressively throughout the season and limit the total number of reproductive cycles of common rust. Our 


\begin{tabular}{|c|c|c|c|c|c|c|c|c|c|c|c|c|}
\hline \multirow[b]{5}{*}{ Generation } & \multicolumn{12}{|c|}{ Cross } \\
\hline & \multicolumn{4}{|c|}{$1267 \times \mathrm{C} 13$} & \multicolumn{4}{|c|}{$1278 \times \mathrm{C} 13$} & \multicolumn{4}{|c|}{$1291 \times \mathrm{C} 13$} \\
\hline & \multicolumn{12}{|c|}{ Growth stage } \\
\hline & \multicolumn{2}{|c|}{ V5 } & \multicolumn{2}{|c|}{ R3 } & \multicolumn{2}{|c|}{ V5 } & \multicolumn{2}{|c|}{ R3 } & \multicolumn{2}{|c|}{ V5 } & \multicolumn{2}{|c|}{ R3 } \\
\hline & $\mathbf{M}^{2 y}$ & W & $\mathrm{M}$ & W & $\mathbf{M}$ & $\mathrm{W}$ & $\mathbf{M}$ & $\mathrm{W}$ & $\mathbf{M}$ & $\mathrm{W}$ & $\mathrm{M}$ & $\mathrm{W}$ \\
\hline$\overline{\mathrm{P}_{1}}$ & $1.61 \mathrm{a}$ & $3.03 \mathrm{a}$ & $3.00 \mathrm{a}$ & $3.96 \mathrm{a}$ & $2.29 \mathrm{a}$ & $3.65 \mathrm{a}$ & $2.80 \mathrm{a}$ & $3.51 \mathrm{a}$ & $1.61 \mathrm{a}$ & $3.03 \mathrm{a}$ & $3.00 \mathrm{a}$ & $3.96 \mathrm{a}$ \\
\hline $\mathrm{BC}_{1} \mathrm{P}_{1}$ & $1.43 \mathrm{a}$ & $3.00 \mathrm{a}$ & $3.46 \mathrm{~b}$ & $4.87 \mathrm{~b}$ & $2.92 \mathrm{~b}$ & $5.23 \mathrm{~b}$ & $2.89 \mathrm{a}$ & $3.23 \mathrm{a}$ & $1.43 \mathrm{~b}$ & $3.00 \mathrm{~b}$ & $3.46 \mathrm{a}$ & $4.87 \mathrm{~b}$ \\
\hline$F_{1}$ & $2.33 \mathrm{~b}$ & $3.75 \mathrm{~b}$ & $4.30 \mathrm{c}$ & $6.41 \mathrm{~d}$ & $2.92 \mathrm{~b}$ & $4.90 \mathrm{~b}$ & $3.07 \mathrm{a}$ & $4.11 \mathrm{~b}$ & $2.33 \mathrm{c}$ & $3.75 \mathrm{c}$ & $4.30 \mathrm{~b}$ & $6.41 \mathrm{~b}$ \\
\hline $\mathrm{BC}_{1} \mathrm{P}_{2}$ & $2.77 \mathrm{c}$ & $4.08 \mathrm{~b}$ & $6.47 \mathrm{~d}$ & $8.58 \mathrm{e}$ & $3.40 \mathrm{~d}$ & $4.62 \mathrm{~d}$ & $5.46 \mathrm{c}$ & $7.84 \mathrm{~d}$ & $2.77 \mathrm{~d}$ & $4.08 \mathrm{~d}$ & $6.47 \mathrm{c}$ & $8.58 \mathrm{~d}$ \\
\hline $\mathrm{P}_{2}$ & $3.66 \mathrm{~d}$ & $6.62 \mathrm{~d}$ & $9.00 \mathrm{e}$ & $9.00 \mathrm{f}$ & $3.66 \mathrm{e}$ & $6.59 \mathrm{e}$ & $9.00 \mathrm{~d}$ & $9.00 \mathrm{e}$ & $3.66 \mathrm{~d}$ & $6.62 \mathrm{f}$ & $9.00 \mathrm{~d}$ & $9.00 \mathrm{e}$ \\
\hline $\mathrm{F}_{2}$ & $2.92 \mathrm{c}$ & $4.55 \mathrm{c}$ & $4.15 \mathrm{c}$ & $6.00 \mathrm{c}$ & $3.21 \mathrm{c}$ & $5.84 \mathrm{c}$ & $4.81 \mathrm{~b}$ & $6.82 \mathrm{c}$ & $2.92 \mathrm{~d}$ & $4.55 \mathrm{e}$ & $4.15 \mathrm{~b}$ & $6.00 \mathrm{c}$ \\
\hline LSD & 0.21 & 0.39 & 0.33 & 0.37 & 0.19 & 0.33 & 0.34 & 0.38 & 0.33 & 0.44 & 0.57 & 0.60 \\
\hline
\end{tabular}

${ }^{2}$ Mean (M) and worst leaf (W) disease severity.

${ }^{y}$ Means with different letters within each column are significantly different $(\mathrm{P} \leq 0.05)$.

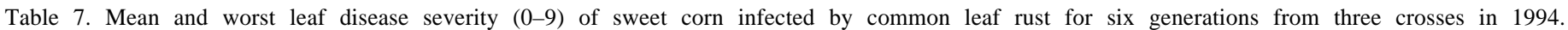

\begin{tabular}{|c|c|c|c|c|c|c|c|c|c|c|c|c|}
\hline \multirow[b]{5}{*}{ Generation } & \multicolumn{12}{|c|}{ Cross } \\
\hline & \multicolumn{4}{|c|}{$1267 \times \mathrm{C} 13$} & \multicolumn{4}{|c|}{$1278 \times \mathrm{C} 13$} & \multicolumn{4}{|c|}{$1291 \times \mathrm{C} 13$} \\
\hline & & & & & & Growth & stage & & & & & \\
\hline & \multicolumn{2}{|c|}{ V5 } & \multicolumn{2}{|c|}{ R3 } & \multicolumn{2}{|c|}{ V5 } & \multicolumn{2}{|c|}{ R3 } & \multicolumn{2}{|c|}{ V5 } & \multicolumn{2}{|c|}{ R3 } \\
\hline & $\mathrm{M}^{2 y}$ & $\mathrm{~W}$ & $\mathbf{M}$ & $\mathrm{W}$ & $\mathrm{M}$ & $\mathrm{W}$ & $M$ & $\mathrm{~W}$ & $\mathrm{M}$ & $\mathrm{W}$ & $\mathbf{M}$ & $\mathrm{W}$ \\
\hline$P_{1}$ & $2.11 \mathrm{a}$ & $3.33 \mathrm{a}$ & $3.00 \mathrm{a}$ & $3.83 \mathrm{a}$ & $2.95 \mathrm{a}$ & $3.95 \mathrm{ab}$ & $2.60 \mathrm{a}$ & $3.15 \mathrm{a}$ & $1.35 \mathrm{a}$ & $2.58 \mathrm{a}$ & $1.76 \mathrm{a}$ & $2.94 \mathrm{a}$ \\
\hline $\mathrm{BC}_{1} \mathrm{P}_{1}$ & $2.75 \mathrm{~b}$ & $3.75 b c$ & $3.00 \mathrm{a}$ & $3.87 \mathrm{a}$ & $2.91 \mathrm{a}$ & $4.08 \mathrm{~b}$ & $3.16 \mathrm{~b}$ & $4.00 \mathrm{~b}$ & $2.09 \mathrm{~b}$ & $3.19 \mathrm{~b}$ & $2.04 \mathrm{a}$ & $3.04 \mathrm{a}$ \\
\hline$F_{1}$ & $2.70 \mathrm{~b}$ & $3.52 \mathrm{ab}$ & $3.76 \mathrm{~b}$ & $5.23 \mathrm{~b}$ & $2.90 \mathrm{a}$ & $3.55 \mathrm{a}$ & $3.10 \mathrm{~b}$ & $4.40 \mathrm{c}$ & $2.76 \mathrm{c}$ & $3.66 \mathrm{c}$ & $3.00 \mathrm{~b}$ & $3.57 \mathrm{~b}$ \\
\hline $\mathrm{BC}_{1} \mathrm{P}_{2}$ & $3.80 \mathrm{c}$ & $5.73 \mathrm{~d}$ & $4.80 \mathrm{c}$ & $6.93 \mathrm{~d}$ & $3.64 \mathrm{~b}$ & $5.59 \mathrm{c}$ & $4.47 \mathrm{~d}$ & $6.47 \mathrm{e}$ & $3.40 \mathrm{~d}$ & $5.10 \mathrm{~d}$ & $3.90 \mathrm{~d}$ & $5.70 \mathrm{~d}$ \\
\hline$P_{2}$ & $4.23 \mathrm{~d}$ & $5.82 \mathrm{~d}$ & $8.00 \mathrm{~d}$ & $9.00 \mathrm{e}$ & $4.23 \mathrm{c}$ & $5.82 \mathrm{c}$ & $8.00 \mathrm{e}$ & $9.00 \mathrm{f}$ & $4.23 \mathrm{e}$ & $5.82 \mathrm{e}$ & $8.00 \mathrm{e}$ & $9.00 \mathrm{e}$ \\
\hline $\mathrm{F}_{2}$ & $2.95 \mathrm{~b}$ & $3.91 \mathrm{c}$ & $3.93 \mathrm{~b}$ & $5.95 \mathrm{c}$ & $3.52 \mathrm{~b}$ & $5.59 \mathrm{c}$ & $3.95 \mathrm{c}$ & $5.90 \mathrm{~d}$ & $2.90 \mathrm{c}$ & $3.72 \mathrm{c}$ & $3.39 \mathrm{c}$ & $4.84 \mathrm{c}$ \\
\hline LSD & 0.32 & 0.44 & 0.39 & 0.51 & 0.29 & 0.49 & 0.32 & 0.38 & 0.28 & 0.39 & 0.35 & 0.39 \\
\hline
\end{tabular}

${ }^{\mathrm{z}}$ Mean (M) and worst leaf (W) disease severity.

${ }^{y}$ Means with different letters within each column are significantly different $(P \leq 0.05)$.

research concentrated primarily on differences in FPA at vegetative stages, presumably when late-planted commercial sweet corn plants would first be challenged by common rust. Studies of the effect of plant age on delayed FPA or on LP against common rust have not been conducted.

Differences in delayed FPA among breeding lines suggests that this component may be accurately assessed in field environments. Despite the potential for interplot interference in this host-pathogen system (Randle et al., 1986), there were no significant effects of replicate or plant position within plots for either FPA or disease severity in any of the three experiments. The lack of replicate effects may allow breeders to use single plots of each genotype to identify breeding lines with longer FPA under field epidemics.

The lack of variability for delayed FPA among the commercial hybrids we tested was similar to the lack of variation for LP (Pataky, 1986). The similarity of FPA among commercial hybrids with such large differences in partial resistance suggests that differences in FPA alone are not responsible for partial resistance. Commercial sweet corn hybrids also differed for other components including urediniospore production and uredinial size (Pataky, 1986). Variation also has been detected within breeding lines for uredinial size (Randle et al., 1984; Gingera, unpublished). It is possible that several components of partial resistance may be combined into single sweet corn genotypes.

Date of FPA against common rust of maize appears to be primarily under additive control, but significant dominance was detected in two of the three crosses. Parlevliet (1976) also reported dominant and additive effects for LP against P. hordei in barley. Because the genetic control of delayed FPA is primarily additive (Table 4), selection for greater delayed FPA maybe effective on a line basis. Although there was variation from year to year in mean FPA (Table 1), lines performing well in 1 year generally also had a longer delayed FPA in the second year.

The lack of transgressive segregation for delayed FPA in these crosses was expected. As C 13 was known to be highly susceptible, it probably did not contribute genes for greater delayed FPA. Transgressive segregation was not found in barley against $P$. hordei (Parlevliet, 1976) in long x short LP crosses. Crossing lines with different alleles for longer FPA may produce transgressive segregates with greater delayed FPA.

Genetic control of partial resistance was similar to that of previous reports. Kim and Brewbaker (1977) and Randle et al. (1984) indicated that partial resistance was primarily additive. This high proportion of additive control was consistent in the three crosses used to assess the inheritance of delayed FPA (Table 5). Selection for increased partial resistance and long FPA should be possible due to the lack of relationship between delayed FPA and disease severity.

Delayed FPA represents a new potential component of partial resistance. Differences in delayed FPA may bean integration of LP and infection efficiency effects, but unlike LP or infection efficiency, FPA maybe accurately screened in field environments. By 
noting the time of appearance of the first pustule, resistance against the most virulent races of a pathogen is screened. Parlevliet (1993) indicated that greater levels of partial resistance maybe identified if selection is conducted using the most virulent races of a pathogen. As the race composition of our bulk urediniospore inoculation is unknown, selection for greater FPA may improve resistance to the most virulent races of common rust. Germplasm with greater levels of delayed ETA may provide a component of partial resistance that may be effectively combined with other components such as small pustule (Randle et al., 1984; Pataky, 1986; Gingera, unpublished) and reduced urediniospore production (Pataky, 1986).

\section{Literature Cited}

Brewbaker, J.L. 1983. Chapter 41. Breeding for Disease Resistance. In: T. Kommedahl and P.H. Williams (eds.). Challenging problems in plant health. Amer. Phytopathol. Soc., St. Paul, Minn.

Davis, D. W., W.M. Randle, and J.V. Groth. 1988. Some sources of partial resistance to common leaf rust (Puccinia sorghi) in maize and strategy for screening. Maydica 33: 1-13.

Davis, D. W., C.A. Engelkes, and J.V. Groth. 1990. Erosion of resistance to corn leaf rust in exotic-derived maize during selection for other traits. Phytopathology 80:339-342.

Gamble, E.E. 1962. Gene effects in corn (Zea mays L.). I. Separation and relative importance of gene effects for yield. Can. J. Plant Sci. 42:339-Mx.

Gingera, G. R., D.W. Davis, and J.V. Groth. 1994. Pedigree selection for improved partial resistance to common leaf rust in sweet corn. Crop Sci. 34:615-620.

Groth, J. V., D.W. Davis, R.J. Zeyen, and B.D. Mogen. 1983. Ranking of partial resistance to common rust (Puccinia sorghi Schr.) in 30 sweet corn (Zea mays) hybrids. Crop Prot. 2:219-223.

Groth, J. V., J.K. Pataky, and G.R. Gingera. 1992. Virulence in Eastern North American populations of Puccinia sorghi to $R p$ resistance genes in corn. Plant Dis. 76:1140-1144.

Groth, J.V. and N.V. Rama Raje Urs. 1982. Differences among bean cultivars in receptivity to Uromyces phaseoli var. typica. Phytopathology 72:374-378.

Hayman, B.I. 1958. The separation of epistatic from additive and dominance variation in generation means. Heredity 12:371-390.

Hooker, A.L. 1969. Widely based resistance to rust in corn. Iowa State Univ. Ext. Spec. Rpt. 64:28-34.
Kim, S.K. and J.L. Brewbaker. 1977. Inheritance of general resistance in maize to corn rust Puccinia sorghi Schw. Crop Sci. 17:456461.

Leonard, K.J. and C.C. Mundt. 1983. Methods for estimating epidemiological effects of quantitative resistance to plant diseases. Theoretical Applied Genet. 67:219-230.

Parlevliet, J.E. 1975. Partial resistance to barley leaf rust, P. hordei. I. Effect of cultivar and developmental stage on latent period. Euphytica 24:21-27.

Parlevliet, J.E. 1976. Partial resistance of barley to leaf rust. III. The inheritance of the host plant effect on latent period in four cultivars. Euphytica 25:241-248.

Parlevliet, J.E. 1993. Can horizontal resistance be recognized in the presence of vertical resistance in plants exposed to a mixture of pathogen races? Plant Dis. 73:379.

Pataky, J.K. 1986. Partial resistance in sweet corn hybrid seedlings. Phytopathology 76:702-707.

Pataky, J.K. 1992. A summary of the reactions of sweet corn hybrids to common rust, Stewart's wilt, Northern corn leaf blight and common smut based on disease nurseries from 1984 to 1991. In: R.L. Hughes and B.A. Michaelis (eds.). 1992 Midwest Food Processors Association processing crops manual and proceedings. vol. 4. Madison, Wis.

Randle, W. M., D.W. Davis, and J.V. Groth. 1984. Improvement and genetic control of partial resistance in sweet corn to corn leaf rust: J. Amer. Soc. Hort. Sci. 109:777-781.

Randle, W.M., D.W. Davis, and J.V. Groth. 1986. Interplot interference in field plots with leaf rust of maize. J. Amer. Soc. Hort. Sci. 111:297300.

Rashid, K. 1991. Evaluation of components of partial resistance to rust in flax. Can. J. Plant Pathol. 13:212-217.

Ritchie, S.W. and J.J. Hanway. 1982. How a corn plant develops. Iowa State Univ. of Sci. and Technol. Spec. Rpt. 48

Rufty, R.C. and C.E. Main. 1989. Components of partial resistance to blue mold in six tobacco genotypes under controlled environmental conditions. Phytopathology 79:606-609.

Shaner, G., H.W. Ohm, and R.E. Finney. 1978. Response of susceptible and slow leaf-rusting wheats to infection by Puccinia recondita. Phytopathology 68:471-475.

Wilkinson, C. A., J.P. Murphy, and R.C. Rufty. 1990. Diallel analysis of components of partial resistance to Septoria nodorum in wheat. Plant Dis. 74:47-50.

Zummo, N. 1988. Components contributing to partial resistance in maize to Puccinia polysora. Plant Dis. 72:157-160. 